\title{
Effectiveness of Some Selected Natural Filter Media for On-Site Small-Scale Treatment of Medium Strength Greywater
}

\author{
"ADONADAGA, M-G; ALIMOH, SC; AMPADU, B \\ Department of Environmental Science, Faculty of Earth and Environment Sciences, University for Development Studies, P.O. Box 24, \\ Navrongo, Ghana. \\ *Corresponding Author Email: amelvin@uds.edu.gh
}

\begin{abstract}
Greywater represents a potential resource of water that can be recycled to meet the standards for safe discharge or non-potable uses. This study evaluated the performance of sand, charcoal, and saw dust filters in reducing Biochemical Oxygen Demand $\left(\mathrm{BOD}_{5}\right)$, Total Dissolved Solids (TDS), pH, Phosphatephosphorus $\left(\mathrm{PO}_{4}-\mathrm{P}\right)$, and Nitrate-nitrogen $\left(\mathrm{NO}_{3}-\mathrm{N}\right)$ in greywater. Greywater was fed into a simple filtration system (SFS) with sand, charcoal and saw dust filters each of height $16 \mathrm{~cm}$ in three plastic containers of the same size: internal diameter $19 \mathrm{~cm}$ and height $22 \mathrm{~cm}$ each and operated for two weeks. Sand efficiently reduced the concentrations of $\mathrm{BOD}_{5}$, phosphate-phosphorus $\left(\mathrm{PO}_{4}-\mathrm{P}\right)$ and TDS while charcoal and saw dust were less efficient. Sand, charcoal, and saw dust reduced influent $\mathrm{BOD}_{5}$ by $97.65 \%, 61.20 \%$ and $66.12 \% ; \mathrm{PO}_{4}-\mathrm{P}$ by $99.92 \%, 83.98 \%$ and $20.56 \% ; \mathrm{NO}_{3}-\mathrm{N}$ by $28.30 \%, 58.80 \%$ and $39.21 \%$; and TDS by $47.18 \%, 7.94 \%$ and $29.69 \%$, respectively for the two-week experimental period. Overall, sand appeared to be the most suitable filter for improving greywater quality for discharge or non-potable uses in terms of organic matter reduction. Effective performance of the charcoal and saw dust filters for the treatment of greywater need further investigation.
\end{abstract}

\section{DOI: https://dx.doi.org/10.4314/jasem.v24i5.25}

Copyright: Copyright (C) 2020 Adonadaga et al. This is an open access article distributed under the Creative Commons Attribution License (CCL), which permits unrestricted use, distribution, and reproduction in any medium, provided the original work is properly cited.

Dates: Received: 10 March 2020; Revised: 15 April 2020; Accepted: 24 May 2020

Keywords: Greywater, daily discharge rate, natural filter media, small-scale treatment.

Water resources are continuously experiencing pressure from the depletion caused by anthropogenic activities resulting from rapid urbanization, industrialization and the struggle for water among individuals (Bani-Melhem et al., 2015). Domestic wastewater may be identified as either greywater or black water. Greywater may be defined as the water (aside lavatory water) created from domestic chores including cooking and washing dishes, laundry and bathing (Anda et al., 2010; Al-Mashaqbeh et al., 2012; Mohamed et al., 2013a; Al-Gheethi et al., 2016). In most developing countries, domestic wastewater is discharged directly into the surroundings without proper treatment, with consequent adverse effects on health of plants and animals, economic activities, the quality of groundwater and the environment as a whole (WWAP, 2017). For instance, discharge of untreated or poorly treated greywater has been associated with contamination of natural water and the environment as a whole resulting in about 2.1 million deaths per year from infectious diseases (Gibson et al., 2010; Riffat, 2012; UNICEF/WHO, 2015). The levels of salts, solids, organic load, nitrogen, phosphorus and pathogens in grey water may also differ extensively (Gross et al., 2005) and may be based totally on the quantity of water used (Morel and Diener, 2006).
Recent studies by Travis et al. (2010) and Dalahmeh et al. (2011) have reported organic nutrients together with fats and surfactants as complicated pollutant in grey water and can affect soil and crops and this has triggered the necessity for greywater treatment before discharge. Another study conducted by Travis et al. (2008) reported that oil and grease from grey water may build up in soils and negatively impact the ability of the soils to absorb water. Gross et al. (2005) in their study in the Israeli Negev desert similarly reported that, the accumulation of salts and surfactants within the soil is possible because of the long-time period of irrigating arid soils with grey water, causing damages in soil residences and toxicity to plant life. Consequently, it is important to collect and treat greywater for the health of the public and the environment (Katukiza et al., 2014; Al-Gheethi et al., 2016; Bani-Melhem et al., 2015). Several types of natural filtration processes ranging from low cost simple treatment methods using filter materials such as sand, course-size bricks, charcoal, sawdust, and coconut shell, oyster shell, peat soil and fly ash to expensive and high technology treatment methods like activated sludge process (ASP) and trickling filters (TF) have been reported in literature as capable of treating greywater. This study employed three natural

*Corresponding Author Email: amelvin@uds.edu.gh 
filter media (sand, charcoal and saw dust) in reducing the concentrations of the analyzed parameters in the grey water. According to the Ghana 2010 Population and Housing Census (GSS, 2014), the KassenaNankana East Municipality does not have wastewater treatment system. Hence wastewater is discharged into the environment untreated, and this has the potential to lead to contamination of surface waters, upper soils and ground water (Norah et al., 2015). This may also create obnoxious environment over time and particularly allow pathogenic bacteria and other disease causing microorganisms to proliferate and provide breeding places for mosquitoes. This phenomenon has necessitated a research into identifying cheap and readily available natural media for use in removing some pollutants. The outcome of this research will provide useful information in the broader context of environmental protection and for the purpose of evaluating the suitability of various natural filters for small-scale greywater treatment option. The overall aim of this experimental study was to evaluate the suitability of selected natural filter media for small-scale close-to-nature treatment of greywater for safe discharge into the environment. Specifically, the following objectives were set: a) to determine the quality of the generated greywater as against the WHO standard for waste water, b) to assess the treatment efficiency of the selected natural filter media (sand, charcoal and saw dust), and c) to compare the removal efficiency of the selected natural filter media with time.

\section{MATERIALS AND METHODS}

Study Area: The research was done in the KassenaNankana Municipal of the Upper East region, Ghana. The population of the Municipality, according to the 2010 population and Housing Census, is 109,944, representing $10.5 \%$ of the region's general population (Fig 1). The climatic situation of the Kassena-Nankana Municipality is described by the dry and wet seasons that are stimulated by two air loads - the North-East trade winds and the South-Westerly's (Tropical Maritime). Day temperatures are high recording $42^{\circ}$ Celsius (especially between February and March) and night time temperatures can be as low as $18^{\circ}$ Celsius. The Municipality observes tropical maritime air mass between May and October and has average annual rainfall of $950 \mathrm{~mm}$ (GSS, 2014). The bucket and stopwatch method was used to measure the amount of greywater generated per hour (Goel, 2011; Adonadaga et al., 2019). The bucket and stopwatch method is less expensive and allow for a safe estimation of grey water without directly coming into contact with it (Mohamed et al., 2016). A bucket of a known volume (10L) was placed under the grey water outlet and the time taken to get full was measured using a stop watch.
Measurement of greywater was done at peak hours within a day. Table 1 shows the hourly and daily grey water discharge.

Greywater Estimation: The ECOWAS hall, an allmale student's hall of residence on the Navrongo Campus of the University for Development Studies (UDS) was selected for this study, primarily because greywater from the hall comes from bathrooms, kitchen and laundry activities undertaken by the students.

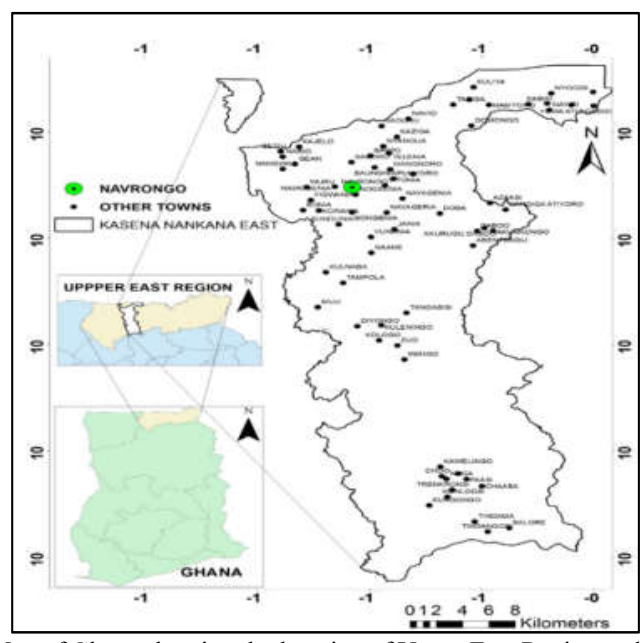

Fig 1. Map of Ghana showing the location of Upper East Region and Kassena-Nankana East Municipal

Table 1. Greywater estimation for hourly and daily discharge.

\begin{tabular}{llll}
\hline Time & $\begin{array}{l}\text { Average } \\
\text { Time } \\
\text { (in hours) }\end{array}$ & $\begin{array}{l}\text { Hourly } \\
\text { Discharge }\left(\mathrm{Q}_{\mathrm{H}}\right)\end{array}$ & $\begin{array}{l}\text { Daily } \\
(\mathrm{h})\end{array}$ \\
$\begin{array}{l}\text { Discharge } \\
\left(\mathrm{Q}_{\mathrm{D}}\right)(\mathrm{l} / \mathrm{h})\end{array}$ \\
\hline Morning & 0.24 & 41.7 & 1000.8 \\
Afternoon & 0.27 & 37.04 & 888.96 \\
Evening & 0.21 & 47.62 & 1142.88 \\
\hline
\end{tabular}

Filter Media Preparation: Three filter materials namely saw dust, charcoal and sand were prepared. These materials are readily available as residual waste materials in the study area. The media were sieved and washed thoroughly with clean water until clarity of drained filtrate was obtained (Mensah and Udofia, 2017). They were then spread on rubber screens and exposed to sunlight to reduce amount of moisture present and also provide an efficient adsorbent surface area. Finer charcoal particles were eliminated as they can rapidly clog the system. Similarly, larger particles were removed as they contribute to the fast flow with less treatment (Niwagaba et al., 2014). 
Experimental Design and Operation: The design consisted of three stages by utilizing polypropylene plastic containers (Zhang and Scholz, 2008) as shown in Fig 2. The first stage of the design employed a container of height $32 \mathrm{~cm}$ and internal diameter of 27 $\mathrm{cm}$ with a capacity of $20 \mathrm{~L}$ which served as greywater feed tank. A PVC pipe with a diameter of $1.5 \mathrm{~cm}$ connects the storage tank $19.5 \mathrm{~cm}$ long at its bottom which leads into the second stage of the design. In this second stage, the pipe from the storage tank is designed to connect the top of three (3) differentcolour plastic containers with the same size: internal diameter $19 \mathrm{~cm}$ and height $22 \mathrm{~cm}$ placed next to each other. The first container (light-blue) from left hand side contains sand filled up to $16 \mathrm{~cm}$, the same height for charcoal in the second container (light-green) and saw dust in the third container (pink). The base of each container in the second stage of the design was perforated and fitted with tubes to permit the flow of effluent from the filter media. The last stage of the design comprised of three transparent polyethylene containers (filtrate containers) of the same height 21.5 $\mathrm{cm}$, internal diameter of $15 \mathrm{~cm}$ and volume of $5 \mathrm{~L}$ each placed at the base of each filter containers to collect the filtrate. Labels were kept on every plastic container for ease of identification.

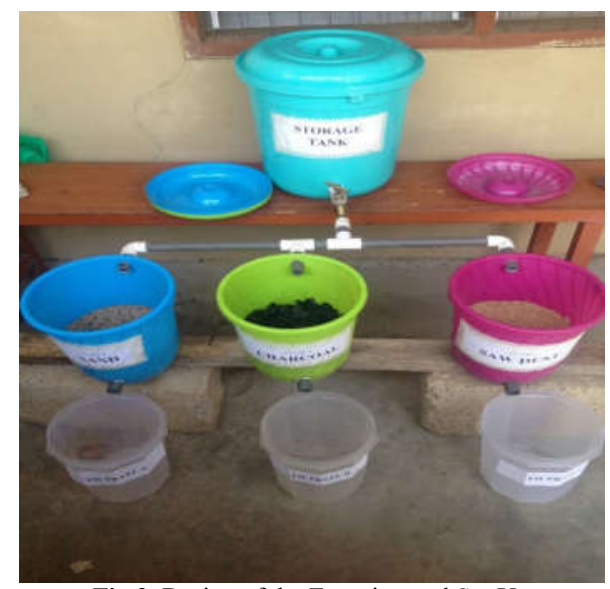

Fig 2. Design of the Experimental Set-Up

The experimental setup was operated for a period of one month, beginning from May, 2019. Gravels were employed as a base support medium for all the filter media. Mosquito net and wire mesh were placed between the gravels and the filter media in order to avoid the smaller grained size media from being washed along with the effluent (Mohamed et al., 2013b). The grey water used for this experiment has not been pre-treated. The greywater was poured into the storage tank and the pipe regulator opened to allow flow by gravity into the three separate containers with the different filter media. The effluent tube was tightly corked to keep the grey water in the filter containers for two days for an effective adhesion and absorption through the liquid-solid physical contact after which the corks were removed and the effluent collected from the collection containers. Effluent samples were labelled and packaged for laboratory analysis.

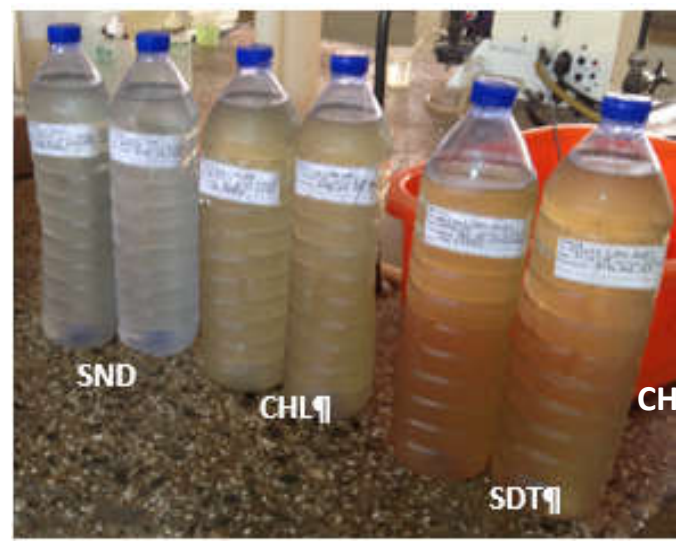

Fig 3: Effluents from Sand (SND), Charcoal (CHL) and Saw dust (SDT)

Laboratory Analysis: Greywater and effluents samples from the various filter media were analyzed for the following parameters according to standard methods (APHA, 2017): Biological Oxygen Demand (BOD 5 ), Phosphate-phosphorus $\left(\mathrm{PO}_{4}-\mathrm{P}\right), \quad$ Nitrate-nitrogen $\left(\mathrm{NO}_{3}-\mathrm{N}\right)$, Total Dissolved Solids (TDS) and $\mathrm{pH}$.

\section{RESULTS AND DISCUSSION}

Greywater Generation: The quantities of greywater discharged hourly and daily from the hall of residence are shown in Fig. 4. It was observed that the discharge peaked in the evening with a discharge of $47.62 \mathrm{l} / \mathrm{h}$ followed by $41.7 \mathrm{l} / \mathrm{h}$ in the morning and $37.04 \mathrm{l} / \mathrm{h}$ being the least in the afternoon. The daily discharges were calculated based on these values, giving an average discharge of $1010.88 \mathrm{l} / \mathrm{d}$. Generally, the quantity of greywater generated is primarily based on the availability of water, living conditions, and residents' habits (Al-Mashaqbeh et al., 2012; Ghaitidak and Yadav, 2013). The variations in discharge may be due to the number of students present at the hall within that time of the day and the patterns of water use. The largest amount of greywater discharge was recorded in the evening. This might be due to the fact that students cook, do their laundry and bath mostly at this time. In relation to greywater generation, Mohammed et al. (2016) have reported that there are three main streams of greywater: the bathroom, the kitchen, and doing laundry. Reasons for the lowest discharge recorded in the afternoon could be because majority of students are out for lectures or library so less greywater generation activities such as bathing, cooking and washing. 


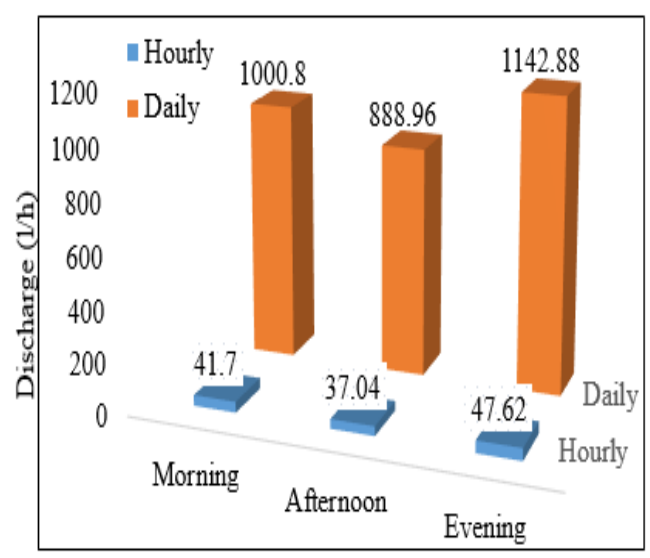

Time

Fig 4. Discharge from the sample site

Greywater Quality: The $\mathrm{pH}$ of 8.3 for the greywater is within the WHO (2006) guideline of $6.5-8.5$ for wastewater discharge. Total Dissolved Solids level in the greywater was $1172 \mathrm{mg} / \mathrm{l}$ which is higher than the guideline value of $1000 \mathrm{mg} / \mathrm{l}$. Biological Oxygen Demand $\left(\mathrm{BOD}_{5}\right)$ concentration was $183 \mathrm{mg} / \mathrm{l}$, exceeding the WHO (2006) guideline value of $50 \mathrm{mg} / \mathrm{l}$. Values of Phosphate-phosphorus $\mathrm{PO}_{4}-\mathrm{P}$ and $\mathrm{NO}_{3}-\mathrm{N}$ were within their guideline values (Fig 5).

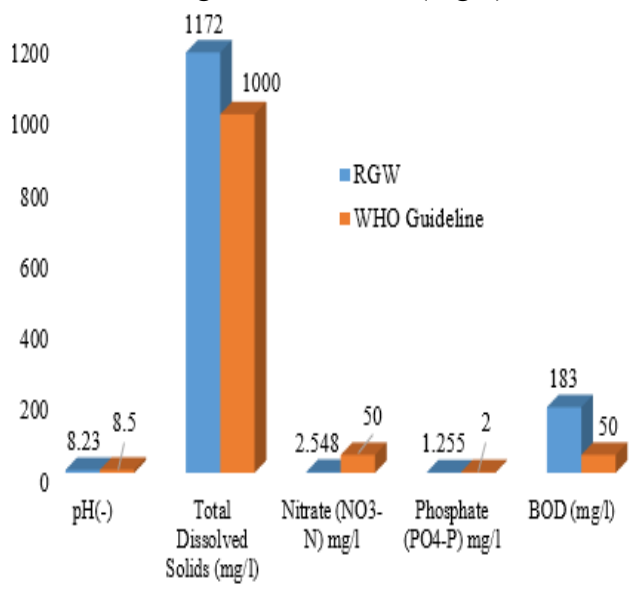

Fig 5: Concentration levels of greywater parameters against WHO (2006) guideline values.

Greywater is enormously low in suspended solids and turbidity, with a greater proportion of the contaminants being mostly dissolved (Al-Jayyousi, 2003). The TDS recorded in this study is similar to the $1404 \mathrm{mg} / 1$ reported by Sonume and Ghate (2004). Niwagaba et al. (2014) stated that the excessive TDS level may be because of the reality that greywater may additionally comprise of an exquisite deal of detergents that have salts and whilst the grey water degrades, the salts crumble and are released resulting in the excessive concentrations. However, Bani-Melhem et al. (2015) have reported lower TDS levels of $319 \mathrm{mg} / \mathrm{l}$ where the bathroom greywater was accrued from a building of the Faculty of Natural Resources on the Hashemite College, AL-Zarqa, Jordan and have attributed this to the source and the type of soap products used by the employees in the University. Despite that greywater is generally generated by using cleaning products for body washing, dish washing and laundry, its composition varies with the region and general lifestyle of the citizens (Al-Jayyousi, 2003; Jefferson et al., 2004; Morel and Diener, 2006). The high BOD reported by this study is supported by other studies that reported values between $120-1307 \mathrm{mg} / 1$ (Abdel-Shafy et al., 2014). These high BOD levels have been attributed to the presence of high natural fraction most likely coming from the human body in the course of washing or bathing (Mohammed et al., 2013a). Another source of high BOD may be due to the pieces of food wastes and oil or carbohydrates/starch from washing utensils and cooking.

Filter Media Performance: Sand achieved 88.52\% reduction in BOD, $42.66 \%$ reduction in Total Dissolved Solids (TDS), $89.48 \%$ reduction in $\mathrm{PO}_{4}-\mathrm{P}$ and $28.3 \%$ reduction in $\mathrm{NO}_{3}-\mathrm{N}$ (Table 2). All these effluent values met the discharge guidelines of the WHO (2006).

Table 2. Performance of the various filter media

\begin{tabular}{|c|c|c|c|}
\hline \multirow{2}{*}{$\begin{array}{l}\text { Sand } \\
\text { Parameter }\end{array}$} & \multicolumn{3}{|c|}{ WEEK ONE } \\
\hline & RGW & SND & $\% \mathrm{R}=\frac{R G W-S N D}{R G W} \times 100$ \\
\hline $\mathrm{TDS}(\mathrm{mg} / 1)$ & 1172 & 672 & $\begin{array}{c}R G W \\
42.66 \%\end{array}$ \\
\hline $\mathrm{NO}_{3}-\mathrm{N}(\mathrm{mg} / \mathrm{l})$ & 2.548 & 1.827 & $28.30 \%$ \\
\hline $\mathrm{PO}_{4}-\mathrm{P}(\mathrm{mg} / \mathrm{l})$ & 1.255 & 0.132 & $89.48 \%$ \\
\hline $\mathrm{BOD}_{5}(\mathrm{mg} / \mathrm{l})$ & 183 & 21 & $88.52 \%$ \\
\hline Charcoal & \multicolumn{2}{|c|}{ WEEK ONE } & \\
\hline Parameter & RGW & CHL & $\% \mathrm{R}=\frac{R G W-C H l}{R G W} \times 100$ \\
\hline TDS (mg/l) & 1172 & 1079 & $7.94 \%$ \\
\hline $\mathrm{NO}_{3}-\mathrm{N}(\mathrm{mg} / \mathrm{l})$ & 2.548 & 1.05 & $58.80 \%$ \\
\hline $\mathrm{PO}_{4}-\mathrm{P}(\mathrm{mg} / \mathrm{l})$ & 1.255 & 0.201 & $83.98 \%$ \\
\hline $\mathrm{BOD}_{5}(\mathrm{mg} / \mathrm{l})$ & 183 & 71 & $61.20 \%$ \\
\hline Sawdust & \multicolumn{2}{|c|}{ WEEK ONE } & \\
\hline Parameter & RGW & SDT & $\% \mathrm{R}=\frac{R G W-S D T}{R G W} \times 100$ \\
\hline TDS (mg/l) & 1172 & 951 & $18.86 \%$ \\
\hline $\mathrm{NO}_{3}-\mathrm{N}(\mathrm{mg} / \mathrm{l})$ & 2.548 & 1.549 & $39.21 \%$ \\
\hline $\mathrm{PO}_{4}-\mathrm{P}(\mathrm{mg} / \mathrm{l})$ & 1.255 & 0.997 & $20.56 \%$ \\
\hline $\mathrm{BOD}_{5}(\mathrm{mg} / \mathrm{l})$ & 183 & 62 & $66.12 \%$ \\
\hline
\end{tabular}

Charcoal showed a decrease of $61.2 \%$ in BOD, a slight decrease of $7.94 \%$ in the TDS level, $83.98 \%$ in $\mathrm{PO}_{4}-\mathrm{P}$ reduction and $58.8 \%$ reduction in $\mathrm{NO}_{3}-\mathrm{N}$. However, the percentage reduction in TDS by the charcoal filter media was not enough to render the effluent safe for discharge. For the saw dust media, the reductions achieved are as follows: BOD, $66.12 \%$; TDS $18.86 \%$; 
$\mathrm{PO}_{4}-\mathrm{P} 20.56 \%$ and $\mathrm{NO}_{3}-\mathrm{N} 39.21 \%$ (Table 2). The reductions were adequate for all the analysed parameters to meet the discharge guideline values. A comparison of the performance of the various filter media for BOD and TDS is shown in Figures 6 and 7 respectively below.

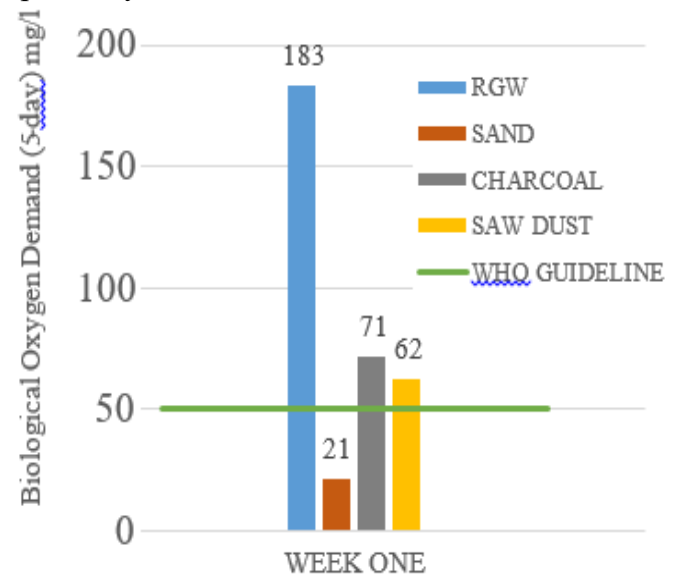

Fig. 6. BOD: Comparison of influent greywater with effluent from the three filter

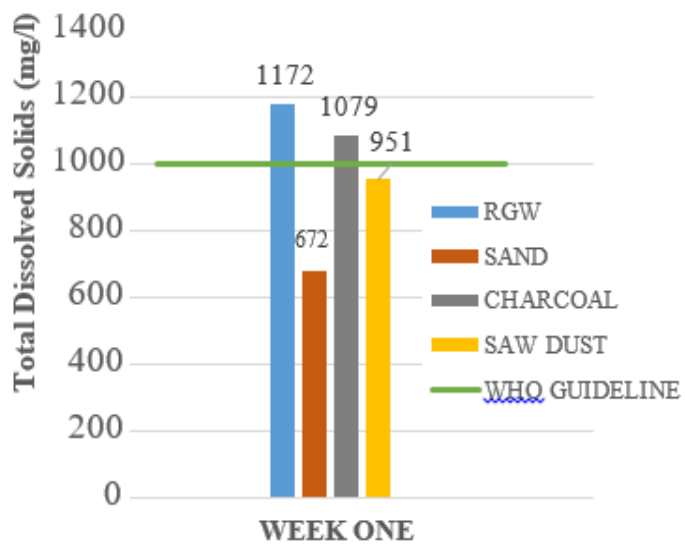

Fig. 7. TDS: Comparison of influent greywater with effluent from the three filter media

$\mathrm{BOD}_{5}$ reductions achieved in this study ranged from $61.20 \%$ to $88.52 \%$, with sand recording the highest and charcoal the lowest. This highest percentage reduction by sand could be because of its high adsorption/retention capacity. The $\mathrm{BOD}_{5}$ reduction achieved by saw dust filter was lower than the $70 \%$ reported by Savage and Tyrel (2005) who used wood chips. Although Ratola et al. (2003) have attributed the reduction of $\mathrm{BOD}_{5}$ in effluent of living filter (bark or sawdust) to adsorption, Dalahmeh et al. (2012) have also associated it to microorganisms which may be present on the filter. The neem charcoal used in this study achieved a $\mathrm{PO}_{4}-\mathrm{P}$ reduction of $83.9 \%$, indicating a higher efficiency compared to the $11-17 \%$ recorded by Ahsan et al. (2001) who used coconut charcoal. A higher adsorption of mineral $\mathrm{PO}_{4}-\mathrm{P}$ compared with the organic forms of phosphate on charcoal could be the reason for the efficiency of the charcoal filter. The $\mathrm{PO}_{4}-\mathrm{P}$ elimination efficiency by the saw dust filter was $20.56 \%$ which is far lower compared to the $97 \%$ reported by Dalahmeh et al. (2012) using tree bark. Possible reasons for this low reduction are the low $\mathrm{PO}_{4}-\mathrm{P}$ concentration in the greywater, the small length of the saw filter and the presence of oil from the kitchen (Travis et al., 2010). Also, the longer the greywater remains in the treatment process, the greater the chance of an effective treatment (Mohammed et al., 2016). The $\mathrm{PO}_{4}-\mathrm{P}$ reduction of $89.48 \%$ by the sand filter was also higher than the $58 \%$ reduction reported by Tamini et al. (2010). Adsorption is the major mechanism for $\mathrm{PO}_{4}-\mathrm{P}$ reduction in sand filter and the potential of the sand to bind phosphorus is based totally on $\mathrm{pH}$ and the $\mathrm{Ca}, \mathrm{Fe}$ and $\mathrm{Al}$ content of materials inside the sand (Pell and Nyberg, 1989; Arias et al., 2001). The $39.12 \% \mathrm{NO}_{3}-\mathrm{N}$ reduction efficiency recorded by this study is similar to the $35 \%$ reduction reported by Lens et al. (1993). Dalahmeh et al. (2012) have stated that aerobic conditions may prevail in living filter (bark or saw dust) which is associated with the nitrification of most of the mineralized nitrogen. This could partly explain the low reduction achieved. Although charcoal achieved the highest $\mathrm{NO}_{3}-\mathrm{N}$ reduction $(58.80 \%)$, this was still lower than the $96.6 \%$ and $90.94 \%$ reported for bio charcoal and activated charcoal (Healy et al., 2007; Berger, 2012).

Conclusion: The study was conducted to assess the suitability of some natural materials for use in treating greywater within the Kassena-Nankana East Municipality. The sand filter was found to be the most efficient as it recorded the highest removal efficiency for TDS, $\mathrm{PO}_{4}-\mathrm{P}$ and $\mathrm{BOD}_{5}$. It is recommended that the experiment be run for a longer time, preferably a month, in order for a proper correlation between the removal efficiency and time to be established. Also, a column filtration system of the three media, based on their porosity, effective surface area and bulk densities should be developed and tested.

\section{REFERENCES}

Abdel-Shafy, HI; El-Khateeb, MA; Shehata, M (2014). Greywater treatment usingdifferent designs of sand filters. Desalination and Water Treatment, 52 (28-30): 5237-5242

Adonadaga, M-G; Jabab, E; Afedo, SK (2019). Domestic Wastewater Characterization and Potential for Treatment Using Close-to-Nature Methods. Journal of Environment and Earth Science, 9 (3): 51 - 59. 
Ahsan, S; Kaneco, S; Ohta, K; Mizuno, T; Kani, K (2001). Use of some natural materials and waste materials for waste water treatment. Water Research, 35 (15): 3738 - 3742

Arias, CA; Del, BM; Brix, H (2001). Phosphorus removal by sands for use as media in subsurface flow constructed reed beds. Water Research, 35 (5): 1159-1168.

Al-Gheethi, AA; Mohamed, RMSR; Efaq, AN; Amir, HK (2016). Reduction of Microbial Risk Associated with Graywater Utilized for Irrigation: A Review. Journal of Water and Health, 14 (3): 379-397

Al-Jayyousi, OR (2003). Grey water reuse: towards sustainable water management. Desalinization 156: $181-192$.

Al-Mashaqbeh, OA; Ghrair, AM; Megdal, SB (2012). Gray Water Reuse for Agricultural Purposes in the Jordan Valley: Household Survey Results in Deir Alla. Water, 4 (3): 580 - 596

Anda, M; Mohamed, RMSR; Mathew, K; Dallas, S; Ho, GE (2010). Decentralized Wastewater Treatment and Recycling in Urban Villages. Water Practice and Technology, 5 (3): $1-11$

APHA/ AWWA/ WEF (2017). Standard Methods for the Examination of Water and Wastewater. $23^{\text {th }}$ Edition, American Public Health Association/ American Water Works Association/ Water Environment Federation, Washington D.C

Bani-Melhem, K; Al-Qodah, Z; Al-Shannag, M; Qasaimeh, A; Qtaishat, MR; Alkasrawi, M (2015). On the Performance of Real Grey Water Treatment Using a Submerged Membrane Bioreactor System. Journal of Membrane Science, 476: 40-49.

Berger, C (2012). Biochar and Activated Carbon Filters for Grey Water Treatment: Comparison of Organic Matter and Nutrient Removal. Unpublished Master Thesis, Env. EURO, Swedish University of Agricultural Sciences, Uppsala, Sweden.

Dalahmeh, SS; Hylander, LD; Vinnerås, B; Pell, M; Öborn, I; Jönsson, H (2011). Potential of organic filter materials for treating greywater to achieve irrigation quality: a review. Water Science and Technology, 63(9): 1832-1840.
Dalahmeh, S; Pell, M; Vinnerås, B; Hylander, L; Öborn, I; Jönsson, H (2012). Efficiency of Bark, Activated Charcoal, Foam and Sand Filters in Reducing Pollutants from Grey water. Water, Air, \& Soil Pollution. 223 (7): 3657 - 3671

Gibson, R; Durán-Álvarez, JC; Estrada, KL; Chávez, A; Cisneros, BJ (2010). Accumulation and Leaching Potential of Some Pharmaceuticals and Potential Endocrine Disruptors in Soils Irrigated with Wastewater in the Tula Valley, Mexico. Chemosphere 81(11): 1437-1445.

Goel, PK (2011). Water Pollution: Causes, effects and control. New Age International Publications. New Delhi.

Gross, A; Azulai, N; Oron, G; Ronen, Z; Arnold M and Nejidat, A (2005). Environmental impacts and health risks associated with greywater irrigation: A case study. Water Science and Technology, 52 (8): $161-169$

Ghaitidak, DM; Yadav, KD (2013). Characteristics and Treatment of Greywater-A Review. Environmental Science and Pollution Research, 20(5): 2795-2809

Ghana Statistical Service, Population and Housing Census (2014). Kassena Nankana East Municipality, www.statsghana.gov.gh.

Healy, G; Rodgers, M; Malqueen, J (2007). Performance of a stratified sand filter in removal of chemical oxygen demand, total suspended solids and ammonia nitrogen from high strength wastewaters. J. Environ. Manage. 83: 409-415

Jefferson, B; Palmer, A; Jeffrey, P; Stuetz, R; Judd, S (2004). Grey water characterization and its impact on the selection and operation of technologies for urban reuse. Water Science and Technology, 50 (2): $157-164$

Mensah, IT; Udofia, EA (2018). Bio-sand Filtration as a Green Approach to Septic Tank Effluent Management in a Tertiary Institution in Ghana. West African Journal of Applied Ecology, 26: 203-216

Mohamed, RMSR; Kassim, AH; Anda, M; Dallas, S (2013a). A Monitoring of Environmental Effects from Household Greywater Reuse for Garden Irrigation. Environmental Monitoring and Assessment, 185: 8473-8488 
Mohamed, RMSR; Chan, CM; Ghani, H; Mat-Yasin, MA; Kassim, AHM (2013b). Application of Peat Filter Media in Treating Kitchen Wastewater. International Journal of Zero Waste Generation, 1 (1): 11-16.

Mohamed, RMSR; Al-Gheeti, AA; Miau, JA; Kassim, AHM (2016). Multi-component Filters for Domestic Greywater Treatment in Village Houses. Journal of American Water Works Association, 108: E405 - E415.

Morel, A; Diener, S (2006). Greywater management in low and middle-income countries, review of different treatment systems for households or neighbourhoods - Sandec Report No. 14/06. Sandec (Water and Sanitation in Developing Countries) at Eawag (Swiss Federal Institute of Aquatic Science and Technology), Dübendorf, Switzerland.

Niwagaba, CB; Dinno, P; Wamala, I; Dalahmeh, SS; Lalander, C; Jönsson, H (2014). Experiences on the Implementation of a Pilot Grey Water Treatment and Reuse Based System at a Household in the Slum of Kyebando- Kisalosalo, Kampala. Journal of Water Reuse and Desalination, 4(4): 294-307

Norah, M; Shumirai, Z; Zelma, ML; Upenyu, M (2015). Impacts of Untreated Sewage Discharge on Water Quality of Middle Manyame River: A Case of Chinhoyi Town, Zimbabwe. International Journal of Environmental Monitoring and Analysis. 3 (3): 133-138.

Pell, M; Nyberg, F (1989). Infiltration of wastewater in a newly started pilot sand-filter system: I. Reduction of organic matter and phosphorus. Journal of Environmental Quality, 18: 451-457

Ratola, N; Botelho, C; Alves, A (2003). The use of pine bark as a natural adsorbent for persistent organic pollutants - study of lindane and heptachlor adsorption. Journal of Chemical Technology and Biotechnology, 78 (3): 347-351
Redwood, M (2008). Greywater irrigation: Challenges and opportunities. In CAB Reviews: Perspectives in Agriculture, Veterinary Science, Nutrition and Natural Resources; CAB International: London, UK; No. 063.

Riffat, R (2012). Fundamentals of Wastewater Treatment and Engineering. CRC Press, Boca Raton.

Sonune, A; Ghate, R. (2004). Developments in wastewater treatment methods. Desalination 167 : $55-63$

Tamini, AH; Freitas, RJ; Suleiman, W (2010). Developing a Manual for Management of Sludge and Biosolids at Jordanian Wastewater Treatment Plant. A Technical Report for International Arid Lands Consortium, University of Arizona, USA.

Travis, MJ; Wiel-Shafran, A; Weisbrod, N; Adar, E; Gross, A (2010). Greywater Reuse for Irrigation: Effect on soil properties. Science of the Total Environment, 408 (12), 2501-2508

UNICEF/WHO (2015). Progress on Sanitation and Drinking Water - 2015 update and MDG assessment WHO Press, Geneva Switzerland.

WHO (2006). Overview of Greywater Management Health Considerations. WHO Press, Geneva Switzerland.

WWAP (United Nations World Water Assessment Programme) (2017). The United Nations World Water Development Report 2017. Wastewater: The Untapped Resource. Paris, UNESCO

Zhang, L; Scholz, M (2009). Performance comparison of filters with different aggregates. Environmental Progress and Sustainable Energy, 28 (2): 192-201. 